\title{
Electric Power Research Institute Environmental Control Technology Center Report to the Steering Committee
}

\author{
Monthly Report \\ September 1997
}

Work Performed Under Contract No.: DE-FG22-94PC93256

\author{
For \\ U.S. Department of Energy \\ Office of Fossil Energy \\ Federal Energy Technology Center \\ P.O. Box 880 \\ Morgantown, West Virginia 26507-0880
}

By
EPRI ECTC
7725 Lake Road

Barker, New York 14012 


\section{Disclaimer}

This report was prepared as an account of work sponsored by an agency of the United States Government. Neither the United States Government nor any agency thereof, nor any of their employees, makes any warranty, express or implied, or assumes any legal liability or responsibility for the accuracy, completeness, or usefulness of any information, apparatus, product, or process disclosed, or represents that its use would not infringe privately owned rights. Reference herein to any specific commercial product, process, or service by trade

name, trademark, manufacturer, or otherwise does not necessarily constitute or imply its endorsement, recommendation, or favoring by the United States Government or any agency thereof. The views and opinions of authors expressed herein do not necessarily state or reflect those of the United States Government or any agency thereof. 
ELECTRIC POWER RESEARCH INSTITUTE

ENVIRONMENTAL CONTROL TECHNOLOGY CENTER

\author{
REPORT TO THE STEERING COMMITTEE
}

\author{
Monthly Technical Progress Report \\ US/DOE Patent Clearance is not Required \\ Prior to the Publication of this Document
}

September 1997

\author{
Prepared by: \\ EPRI/ECTC \\ Parsons \\ January 12, 1998 \\ DOE Grant \#DE-FG22-94PC93256 --43 \\ EPRI ECTC \\ 7725 Lake Road \\ Barker, New York 14012
}




\section{DISCLAIMER}

This report was prepared as an account of work sponsored by an agency of the United States Government. Neither the United States Government nor any agency thereof, nor any of their employees, makes any warranty, express or implied, or assumes any legal liability or responsibility for the accuracy, completeness, or usefulness of any information, apparatus, product, or process disclosed, or represents that its use would not infringe privately owned rights. Reference herein to any specific commercial product, process, or service by trade name, trademark, manufacturer, or otherwise does not necessarily constitute or imply its endorsement, recommendation, or favoring by the United States Government or any agency thereof. The views and opinions of authors expressed herein do not necessarily state or reflect those of the United States Government or any agency thereof.

\section{CAUTIONS TO USE OF THIS REPORT}

This report is a compilation of monthly progress reports by EPRI contractors (Radian International, Parsons Power) connected with the Environmental Control Technology Center (ECTC). This report is intended to provide timely information regarding the status of testing and research to the ECTC co-sponsoring organizations. All data, results, and remarks contained in this report should be considered preliminary based on the information available to date. Any speculation or conclusions discussed in this report are subject to change as additional information becomes available.

Neither EPRI, members of EPRI, Radian International, Parsons Power, or any person acting on behalf of any of them makes any warranty, express or implied, with respect to the use of any information, apparatus, method, or process disclosed in this report, or that any such use may not infringe privately owned rights. Neither EPRI, members of EPRI, Radian International, Parsons Power, or any person acting on behalf of any of them assumes any liabilities with respect to the use of, or for damages resulting from the use of any information, apparatus, method, or process disclosed in this report.

For further information on:

Facility Operations and Miscellaneous ECTC inquires; contact - Gary Andes (716) 795-3397

Wet FGD/Toxics Testing, Spray Drying/Dry FGD/Duct Injection technologies; contact - Richard Rhudy (415) 855-2421

Air Toxics/Carbon Injection for Mercury Control contact - Ramsay Chang (415) 855-2535 


\section{TABLE OF CONTENTS}

I. EXECUTIVE SUMMARY

II. FACILITY STATUS

- General

- Carbon Injection System

- Financial Report

III. PILOT AND MINI-PILOT TEST ACTIVITY

- Testing Overview

- Summary of Operations

- Summary of Results

- Future Testing

IV. APPENDIX A Test Schedule(s)

V. APPENDIX B Process/Analytical Data Summary 


\section{EXECUTIVE SUMMARY}

\section{General Operations}

Operations and maintenance continued this month at the Electric Power Research Institute's (EPRI's) Environmental Control Technology Center (ECTC). Testing for the month involved the Dry Sorbent Injection (DSI) test block with the Carbon Injection System.

The 1.0 MW Cold-Side Selective Catalytic Reduction (SCR) unit, the 0.4 MW MiniPilot Wet Scrubber, and the 4.0 MW Pilot Wet Scrubber remained idle this month in a cold-standby mode and were inspected regularly. These units remain available for testing as future project work is identified.

\section{Pilot Testing Highlights}

The 1990 Clean Air Act Amendments have required that the Environmental Protection Agency (EPA) assess the health risks and environmental effects associated with air toxic emissions (primarily mercury) from fossil-fuel fired utility boilers. EPRI has sponsored research on environmental mercury since 1983 to determine the factors that may influence human health, and to determine the role of electric power generating stations in contributing to those factors. Over the last four years, EPRI's Environmental Control Technology Center (ECTC) has conducted EPRI and DOE sponsored testing to develop and demonstrate appropriate measurement methods and control technologies for power plant atmospheric mercury emissions.

Building upon the experience and expertise of the EPRI ECTC, a test program was initiated at the Center in July to further evaluate dry sorbent-based injection technologies upstream of a cold-side ESP for mercury control, and to determine the effects of such sorbents on ESP performance. This program was continued in September at the ECTC, and the test results will be compared to test data from previous DOE/EPRI demonstrations, and to other ongoing programs.

The primary objectives of this test program are to:

- Determine the levels of mercury removal achievable by dry sorbent injection upstream of an electrostatic precipitator (ESP). The process parameters to be investigated include sorbent residence time, sorbent type, sorbent size, sorbent loading, and flue gas temperature.

- Determine the impact of sorbent injection on ESP performance. 


\section{FACILITY STATUS}

\section{General}

The NYSEG Kintigh Station provided flue gas to the Center 100\% of the time during this performance period. As the Kintigh Station operated with a variety of coals, fluctuations in the Center's inlet $\mathrm{SO}_{2}$ concentrations were experienced.

Safety training for the month was conducted by the Operations Manager. The training topics this month included safe work with cranes and slings, and the effects of sleep deprivation for shift workers. Inspections of the ECTC Facility and safety equipment (SCR air-packs, fire extinguishers, etc.) were completed and recorded this month. All systems were found to be in good condition. By continuing to emphasize safe work habits at the Center, we have raised the total number of days without a lost time injury to 1944 as of 9/30/97.

The monthly safety meeting with the NYSEG Kintigh Station and the EPRI ECTC was held on September 16, 1997 to exchange information and cover joint issues. The major topics of discussion included the ECTC's Phase I environmental site assessment (ESA) and the future status of the Center's $\mathrm{SO}_{2}$ storage and spiking system.

\section{Pilot and Mini-Pilot Testing}

The equivalent and actual availability for the ECTC Carbon Injection System testing was $100 \%$ during this period. There were no forced or scheduled outages this month.

The Dry Sorbent Injection (DSI) test block continued this month with tests DSI-5; DSI-5a; DSI-6; DSI-7; and DSI-8. The objective of this test block is to study the ECTC electrostatic precipitator (ESP) performance and removal efficiency for total mercury as activated carbon and other sorbents are injected across the ESP. For this testing, the ECTC flue gas path was configured so that the particulate and acid-gas rich dirty raw gas (DRG) from the facility inlet flowed through the Spray Dryer Absorber (SDA) for temperature control, and then through the ESP and the ECTC outlet ductwork. During the test block, a lignite-based activated carbon (FGD carbon from American Norit) was injected upstream of the ESP at different loading rates as the flue gas was sampled for particulate (via method 5), $\mathrm{SO}_{2} / \mathrm{O}_{2}$ (via ECTC CEMs), and mercury concentration (via method 101A). The mercury samples collected from the testing this month were forwarded to Radian International for off-site analysis; ash samples from the ESP and the ECTC ash silo, and coal samples from the Kintigh Station, were collected weekly for archiving and analysis at a later date. The operational parameters for the DSI testing with the Carbon Injection System this period included: gas flow of $10,200 \mathrm{scfm}$; inlet $\mathrm{SO}_{2}$ concentration as received from the Kintigh Station; ESP outlet particulate loading of 0.1-0.2 lb./MMBTU; inlet flue gas temperature of $275^{\circ} \mathrm{F} \pm 5^{\circ} \mathrm{F}$; and activated carbon injection rates of $1.9 ; 4.6$; and 9.2 lb./hr. 
The following maintenance work was completed on the Carbon Injection System during this performance period:

- Regular inspections and calibrations were conducted on the facility CEM systems.

- The carbon feeder was inspected and calibrated.

- Scheduled maintenance was performed on ECTC equipment systems.

- The SDA Solids Evacuation System was inspected and cleaned.

- The upper equalizing air lock valve on the waste silo ash handling system was rebuilt.

\section{Financial Report}

The Financial Report for the four Operations and Maintenance contract tasks are summarized below for the month of September 1997, the year to date, and the contract total.

\section{Task Definitions:}

Task 100: Operations and Maintenance Labor

Task 200: Purchased Materials

Task 300: Engineering Support

Task 400: Training

Table i.

Monthly Operating Costs by Task

\begin{tabular}{|c|c|c|c|c|c|c|}
\hline & \multicolumn{2}{|c|}{ September } & \multicolumn{2}{|c|}{ Year to Date } & \multicolumn{2}{|c|}{ Contract Total } \\
\hline Task 100 & $\$$ & 41,782 & $\$$ & 242,527 & $\$$ & $14,721,536$ \\
\hline Task 200 & $\$$ & 31,335 & $\$$ & 76,382 & $\$$ & $8,587,577$ \\
\hline Task 300 & $\$$ & 7,064 & $\$$ & 88,840 & $\$$ & $1,283,428$ \\
\hline Task 400 & $\$$ & 165 & $\$$ & 228 & $\$$ & 53,463 \\
\hline DOE Grant & $\$$ & - & $\$$ & 132,616 & $\$$ & 248,792 \\
\hline TOTAL & $\$$ & 80,346 & $\$$ & 540,593 & $\$$ & $24,894,796$ \\
\hline
\end{tabular}


The attached graph illustrates the budgeted and actual expenses for ECTC O\&M activities through September 1997.

Figure i.

1997 Operation \& Maintenance Costs

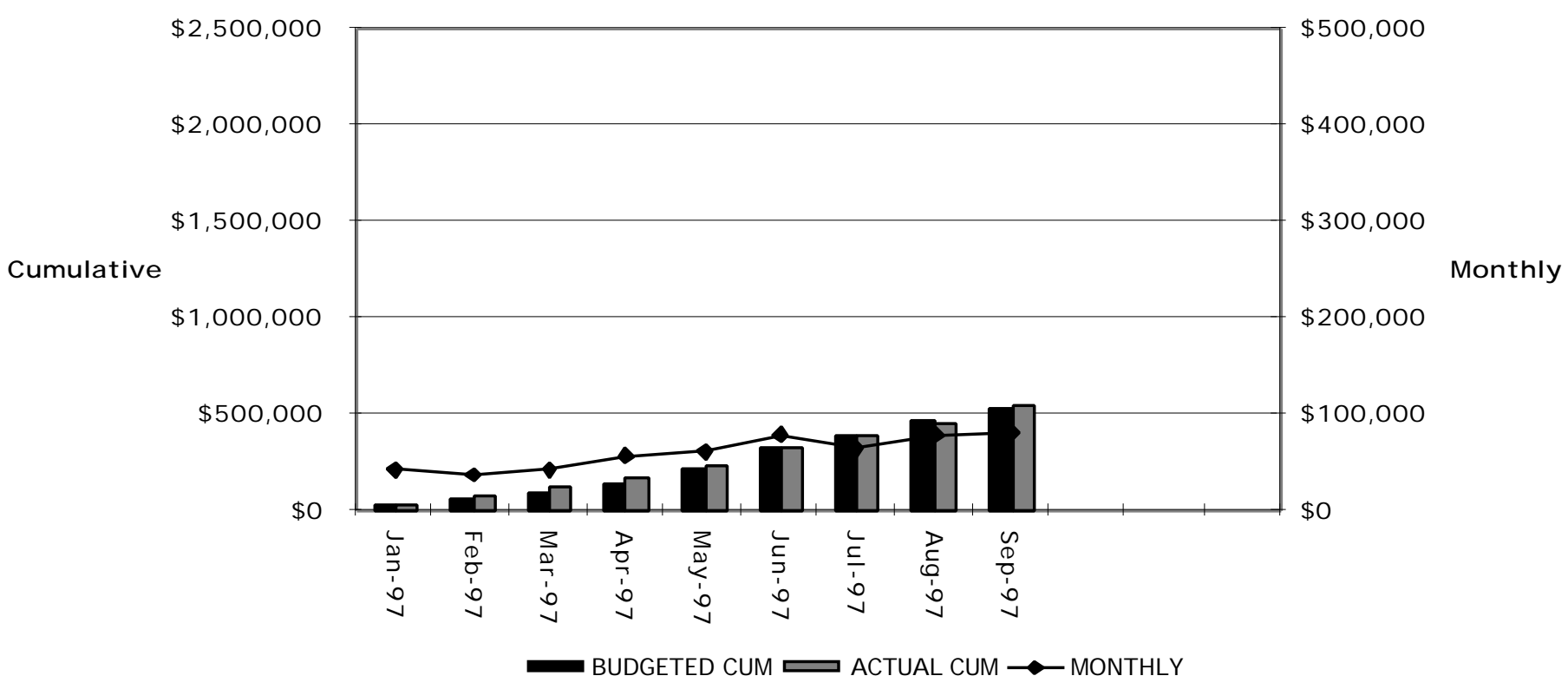




\section{PILOT AND MINI-PILOT TEST ACTIVITY}

\section{Testing Overview}

The 1990 Clean Air Act Amendments have required that the Environmental Protection Agency (EPA) assess the health risks and environmental effects associated with air toxic emissions (primarily mercury) from fossil-fuel fired utility boilers. EPRI has sponsored research on environmental mercury since 1983 to determine the factors that may influence human health, and to determine the role of electric power generating stations in contributing to those factors. Over the last four years, EPRI's Environmental Control Technology Center (ECTC) has conducted EPRI and DOE sponsored testing to develop and demonstrate appropriate measurement methods and control technologies for power plant atmospheric mercury emissions.

Building upon the experience and expertise of the EPRI ECTC, a test program was initiated at the Center in July to further evaluate dry sorbent-based injection technologies upstream of a cold-side ESP for mercury control, and to determine the effects of such sorbents on ESP performance. The results from this program will be compared to the results from previous DOE/EPRI demonstrations, and to other ongoing programs.

The primary objectives of this test program are to:

- Determine the levels of mercury removal achievable by dry sorbent injection upstream of an electrostatic precipitator (ESP). The process parameters to be investigated include sorbent residence time, sorbent type, sorbent size, sorbent loading, and flue gas temperature.

- Determine the impact of sorbent injection on ESP performance. 


\section{Summary of Operations}

The Dry Sorbent Injection (DSI) test block with the Pilot Spray Dryer Absorber (SDA) and electrostatic precipitator (ESP) began during the first week of July and continued through September. The process configuration for this testing (with sampling and injection points) is shown below in Figure 1.

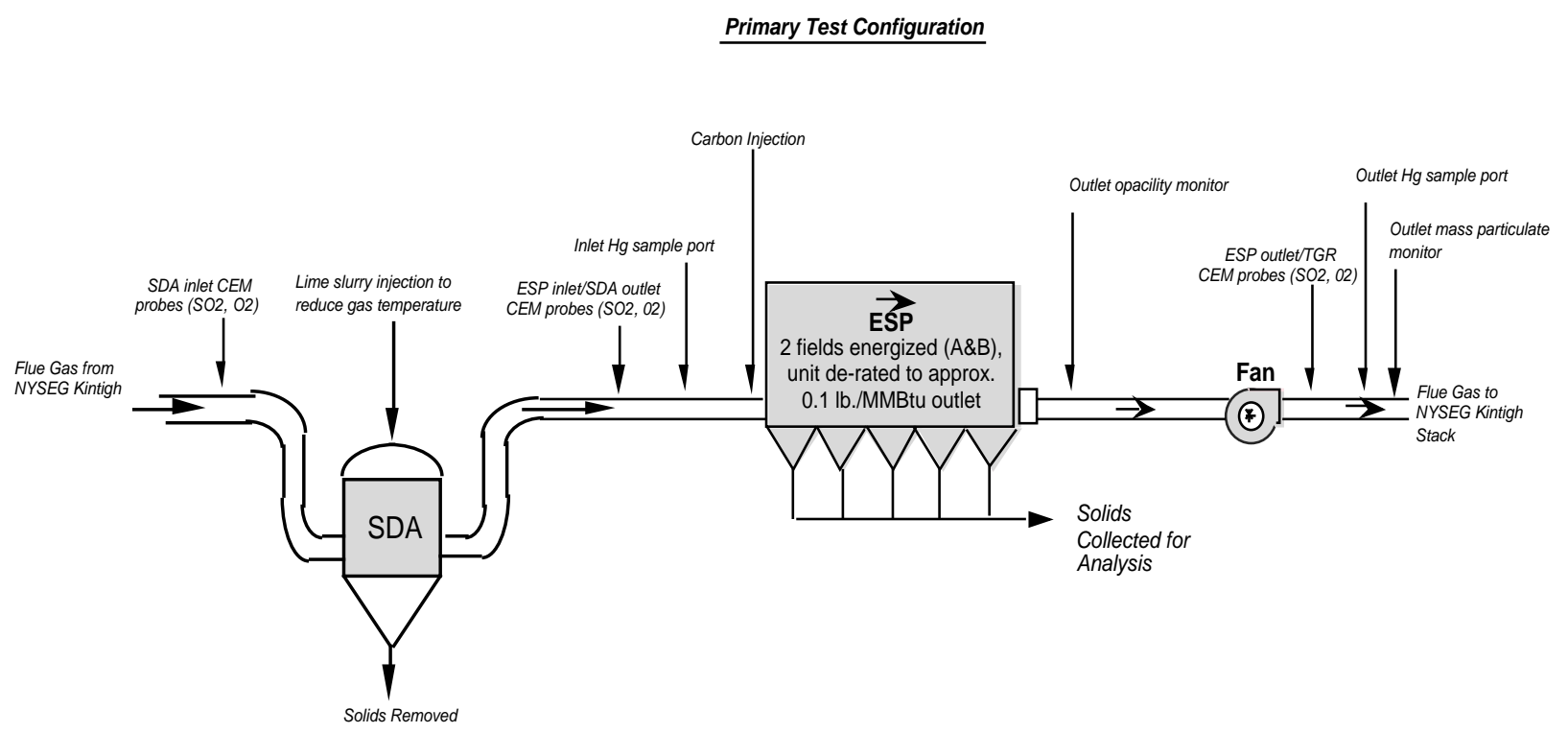

Figure 1. Process Flow Diagram for Dry Sorbent Injection (DSI) Test Block

During this test program, a commercial carbon based sorbent (activated FGD carbon from American Norit) was studied for injection into the ECTC flue gas stream for mercury control. At the Center, testing was conducted primarily across the cold-side ESP (5.0 MW equivalent gas flow). For this testing, the ECTC ESP was configured to simulate a retrofit application utilizing a small (1-2 field) unit; the ESP was also calibrated and detuned to produce a baseline outlet mass particulate emission of 0.1$0.2 \mathrm{lb} / \mathrm{MBtu}$. Upstream of the ESP, the flue gas mercury concentration was measured using EPA Method 101A. Several of the other inlet flue gas parameters/species $\left(\mathrm{SO}_{2}, \mathrm{O}_{2}, \mathrm{HCl}\right.$, etc.) were also continuously monitored and adjusted to meet testing requirements and determine their effects on mercury removal.

Downstream from the ESP inlet sampling point, the activated carbon was injected into the ESP with mercury sampling at the ESP outlet to determine removal efficiency. Periodic sampling of the collected flyash/carbon solids was also conducted to help determine particulate removal efficiencies across the ESP, and to determine the impact of carbon injection on flyash loss on ignition (LOI). Also, with the characterization data on the inlet flue gas composition and monitoring of the ESP operation, the particulate collection efficiency of the ESP was recorded to determine any degradation effects as the activated carbon was injected into the system. 
This month's testing continued at 10,200 scfm with an ESP inlet temperature of $275^{\circ} \mathrm{F}$. The September test matrix started with a carbon injection rate of $10 \mathrm{lb} / \mathrm{Macf}$, and continued with the lower injection rates of $5 \mathrm{lb} /$ Macf and $2 \mathrm{lb} /$ Macf. At the conclusion of the month, the ESP inlet temperature was increased to $300^{\circ} \mathrm{F} \pm 5^{\circ} \mathrm{F}$ to repeat some earlier tests from the August and July matrix at a more controlled ESP inlet temperature. Also, the SDA flow venturi was calibrated at the beginning of the month. A summary of the operating conditions in September is presented in Table 1.

\section{Table 1. September 1997 Dry Sorbent Injection (DSI) Operating Summary}

\begin{tabular}{|c|c|c|}
\hline Date & Test Description & Operation Summary \\
\hline $\begin{array}{l}\text { Mon. } \\
\text { Sept. 1, } 97\end{array}$ & $\begin{array}{l}\text { DSI-5, Carbon } \\
\text { Injection }(10,200 \\
\text { scfm, } 275^{\circ} \mathrm{F}, 9.2 \\
\mathrm{lb} / \mathrm{hr}) \mathrm{ESP} \mathrm{A}, \mathrm{B} \\
(5)\end{array}$ & LABOR DAY - FACILITY DOWN \\
\hline $\begin{array}{l}\text { Tue. } \\
\text { Sept. 2,97 }\end{array}$ & $\begin{array}{l}\text { DSI-5, Carbon } \\
\text { Injection }(10,200 \\
\text { scfm, } 275^{\circ} \mathrm{F}, 9.2 \\
\text { lb/hr) ESP A,B } \\
\text { (5) }\end{array}$ & $\begin{array}{l}\text { At 04:00 the CEMs, P-5A, and opacity monitor were calibrated. } \\
\text { Opacity values seemed lower then previously. A Method } 5 \text { was } \\
\text { started at the ESP outlet at } 08: 48 \text { and finished at } 10: 30 \text {, with a } \\
\text { result of } 0.105 \mathrm{lb} / \mathrm{MMBtu}(\mathrm{P}-020) \text {. Contractors meeting held at } \\
\text { 13:00, discussed weeks testing, shipping samples, LOI } \\
\text { calculation, summaries, and ESP plots. }\end{array}$ \\
\hline $\begin{array}{l}\text { Wed. } \\
\text { Sept. 3,97 }\end{array}$ & $\begin{array}{l}\text { DSI-5, Carbon } \\
\text { Injection }(10,200 \\
\text { scfm, } 275^{\circ} \mathrm{F}, 9.2 \\
\text { lb/hr) ESP A,B } \\
\text { (5) }\end{array}$ & $\begin{array}{l}\text { Carbon injection started at } 05: 00 \text { at } 9.2 \mathrm{lb} / \mathrm{hr} \text {. Method } 101 \mathrm{~A} \text { was } \\
\text { started at both the inlet and outlet to the ESP at } 08: 18 \text {, and run \# } 2 \\
\text { was completed at 11:00. Carbon started at } 8.4 \mathrm{lb} / \mathrm{hr} \text { and ended at } \\
8.7 \mathrm{lb} / \mathrm{hr} \text { during sampling. The VSD is being investigated by the } \\
\text { electrician. NO carbon to be injected over night or in the morning. }\end{array}$ \\
\hline $\begin{array}{l}\text { Thur. } \\
\text { Sept. 4, } 97\end{array}$ & $\begin{array}{l}\text { DSI-5, Carbon } \\
\text { Injection }(10,200 \\
\text { scfm, 275F, } 9.2 \\
\text { lb/hr) ESP A,B } \\
(5)\end{array}$ & $\begin{array}{l}\text { Mercury samples were prepared to be sent to Radian for analysis. } \\
\text { Shipped } 4 \times 250 \mathrm{ml} \text { samples in } 1 \text { paint can, } 2 \text { paint cans per box, } \\
\text { and sent } 3 \text { boxes, for a total of } 24 \text { samples ( } 6 \text { days). Velocity } \\
\text { traverses were conducted at } 10,200 \text { scfm and } 275^{\circ} \mathrm{F} \text { at the SDA } \\
\text { inlet and the ESP outlet. ESP outlet results taken at } 13: 47 \text { were } \\
12,164 \text { scfm. This is close to what we have recorded in the past. } \\
\text { This is due to in leakage across the ESP and the ESP fan. The } \mathrm{O}_{2} \\
\text { readings from the CEMs support this value. The SDA inlet taken } \\
\text { at } 14: 05 \text { showed } 10,716 \mathrm{scfm}(4.8 \% \text { difference). At } 15: 30 \text { the inlet } \\
\text { temperature to the ESP was raised to } 300^{\circ} \mathrm{F} \text {, and turned off } \\
\text { "A\&B" fields and switched to "C\&E" fields. }\end{array}$ \\
\hline $\begin{array}{l}\text { Fri. } \\
\text { Sept. 5, } 97\end{array}$ & $\begin{array}{l}\text { DSI-5, Carbon } \\
\text { Injection }(10,200 \\
\text { scfm, 275F, } 9.2 \\
\text { lb/hr) ESP A,B } \\
\text { (5) }\end{array}$ & $\begin{array}{l}\text { At } 04: 00 \text { The ESP inlet temperature was decreased to } 275^{\circ} \mathrm{F} \text {. At } \\
\text { 6:00 the ESP was switched back to "A\&B" fields, and taps were } \\
\text { blown out. It was noticed that pressure taps need to be blown back } \\
\text { more often. Due to an increase in flow which leads to an } \\
\text { increased load, which gradually builds between blow backs. At } \\
\text { 6:45 rappers were reset, and the inlet temp was at } 276^{\circ} \mathrm{F} \text { and the } \\
\text { outlet was at } 279^{\circ} \mathrm{F} \text { still. At } 7: 55 \text { the carbon injector was turned on } \\
\text { and a Method } 101 \mathrm{~A} \text { was started at } 9: 23 \text {. At } 10: 24 \text { sampling was } \\
\text { finished only doing } 1 \text { run. Carbon was turned off at } 11: 30 \text {. The } \\
\text { pressure taps were blown back at } 13: 00 \text { and no change was noticed. } \\
\text { Also the flow hose to the venturi were replaced. The facility } \\
\text { was purged at } 13: 30 \text {. }\end{array}$ \\
\hline
\end{tabular}


Table 1. September 1997 Dry Sorbent Injection (DSI) Operating Summary (cont.)

\begin{tabular}{|c|c|c|}
\hline Date & Test Description & Operation Summary \\
\hline $\begin{array}{l}\text { Mon. } \\
\text { Sept. 8, } 97\end{array}$ & $\begin{array}{l}\text { DSI-5a, Carbon } \\
\text { Injection }(10,200 \\
\text { scfm, } 275^{\circ} \mathrm{F}, 9.2 \\
\mathrm{lb} / \mathrm{hr}) \mathrm{ESP} \mathrm{A}, \mathrm{B} \\
(5)\end{array}$ & $\begin{array}{l}\text { At } 04: 00 \text { the I\&C dept. calibrated the CEMs, P-5A, and opacity } \\
\text { monitor. Everything report as being fine. The P-5A and opacity } \\
\text { were running lower then usual baseline conditions. A VT was } \\
\text { performed on the SDA inlet and ESP outlet again, followed by } \\
\text { the taps being blown. There was about a } .5 \% \text { reduced on the } \% \\
\text { error. The ESP was switched to "B field" only, and a Method } 5 \\
\text { was done at } 12: 48 \text {. The mass loading resulted (P-021) in } 0.325 \\
\mathrm{lb} / \mathrm{MMBtu} \text {. The ESP was switched back to "A\&B fields". It } \\
\text { seems to be at the lower temperature (275F) it take longer for the } \\
\text { loading to baseline after start up. }\end{array}$ \\
\hline $\begin{array}{l}\text { Tue. } \\
\text { Sept. 9, } 97\end{array}$ & $\begin{array}{l}\text { DSI-5a, Carbon } \\
\text { Injection }(10,200 \\
\text { scfm, 275F, } 9.2 \\
\mathrm{lb} / \mathrm{hr}) \text { ESP A,B } \\
\text { (5) } \\
\end{array}$ & $\begin{array}{l}\text { Carbon was started at } 05: 00 \text {, injection rate of } 9.2 \mathrm{lb} / \mathrm{hr} \text {. A method } \\
101 \mathrm{~A} \text { was started at } 08: 30 \text { and a run } \# 2 \text { at } 9: 48 \text {. Continued with } \\
\text { carbon injection through the evening. The range in feeder was } \\
8.24-9.1 \mathrm{lb} / \mathrm{hr} \text {. }\end{array}$ \\
\hline $\begin{array}{l}\text { Wed. } \\
\text { Sept. 10, } 97\end{array}$ & $\begin{array}{l}\text { DSI-5a, Carbon } \\
\text { Injection }(10,200 \\
\text { scfm, 275F, } 9.2 \\
\mathrm{lb} / \mathrm{hr}) \text { ESP A,B } \\
\text { (5) }\end{array}$ & $\begin{array}{l}\text { Carbon through the night, and a Method 101A started at } 08: 18 \\
\text { and 9:37. Note that the first impinger at the ESP inlet turned } \\
\text { clear by the end of the sample run. Mercury analysis numbers } \\
\text { arrived from Radian, and were put into the summary plots and } \\
\text { tables. Some of the numbers received needed to be re-ran, due to } \\
\text { sample being above standard. A meeting was held with on site } \\
\text { personnel to go over plots of mercury testing and ESP performance, } \\
\text { and to go over future testing matrix. }\end{array}$ \\
\hline $\begin{array}{l}\text { Thur. } \\
\text { Sept. 11, } 97\end{array}$ & $\begin{array}{l}\text { DSI-5a, Carbon } \\
\text { Injection }(10,200 \\
\text { scfm, } 275^{\circ} \mathrm{F}, 9.2 \\
\mathrm{lb} / \mathrm{hr}) \text { ESP A,B } \\
\text { (5) }\end{array}$ & $\begin{array}{l}\text { Some time between } 03: 30-05: 00 \text { the carbon injection system went } \\
\text { down. A Method 101A was started at } 8: 10 \text { and 9:27. The re-ran } \\
\text { mercury analysis were put into plots and tables. At } 16: 50 \text { the } \\
\text { carbon hopper was ran empty and cleaned out (a } 3 / 4 \text { " bolt was } \\
\text { found in the hopper). The ESP was allowed to run for } 3 \text { hours } \\
\text { with no injection to return to baseline conditions. At } 20: 10 \text { fly ash } \\
\text { injection began and ran until 23:15. Again the ESP was allowed to } \\
\text { recover for } 3 \text { hours with no injection. }\end{array}$ \\
\hline $\begin{array}{l}\text { Fri. } \\
\text { Sept. } 12,97\end{array}$ & $\begin{array}{l}\text { DSI-5a, Carbon } \\
\text { Injection }(10,200 \\
\text { scfm, 275F, } 9.2 \\
\mathrm{lb} / \mathrm{hr}) \text { ESP A,B } \\
\text { (5) } \\
\end{array}$ & $\begin{array}{l}\text { Carbon was started at } 02: 10 \text {, at a rate of } 4.6 \mathrm{lb} / \mathrm{hr} \text { and allowed to } \\
\text { run until 17:00. The ESP recovered to baseline values in a half } \\
\text { hour and was then shut down for the weekend. }\end{array}$ \\
\hline $\begin{array}{l}\text { Mon. } \\
\text { Sept. 15, } 97\end{array}$ & $\begin{array}{l}\text { DSI-5a, Carbon } \\
\text { Injection }(10,200 \\
\text { scfm, 275F, } 9.2 \\
\mathrm{lb} / \mathrm{hr}) \text { ESP A,B } \\
\text { (5) }\end{array}$ & $\begin{array}{l}\text { The facility was brought up on flue gas at 23:25. The NYSEG } \\
\text { control room notified the ECTC CR that they detected a leak } \\
\text { between us and FGD, nothing was found. Mercury samples were } \\
\text { prepared to be sent to Radian for analysis. At } 13: 40 \text { a Method } 5 \\
\text { was taken, but was an invalid point. The weekly contractors } \\
\text { meeting was held at 14:00. A P-5A range was left with the } \\
\text { control room for carbon injection start up in the morning. }\end{array}$ \\
\hline $\begin{array}{l}\text { Tue. } \\
\text { Sept. 16, } 97\end{array}$ & $\begin{array}{l}\text { DSI-6, Carbon } \\
\text { Injection }(10,200 \\
\text { scfm, 275F, } 4.6 \\
\mathrm{lb} / \mathrm{hr}) \text { ESP A,B } \\
\text { (5) } \\
\end{array}$ & $\begin{array}{l}\text { Carbon was started at } 05: 00 \text {, at a rate of } 4.6 \mathrm{lb} / \mathrm{hr} \text {. A Method } \\
101 \mathrm{~A} \text { was started at } 8: 20 \text { and } 9: 35 \text { at both the ESP inlet and } \\
\text { outlet. Carbon injection was continued through the night at } \\
4.6 \mathrm{lb} / \mathrm{hr} \text {. }\end{array}$ \\
\hline $\begin{array}{l}\text { Wed. } \\
\text { Sept. 17, } 97\end{array}$ & $\begin{array}{l}\text { DSI-6, Carbon } \\
\text { Injection }(10,200 \\
\text { scfm, } 275^{\circ} \mathrm{F}, 4.6 \\
\mathrm{lb} / \mathrm{hr}) \text { ESP A,B } \\
(5)\end{array}$ & $\begin{array}{l}\text { Carbon injection through the night ranged from } 5.01-3.87 \mathrm{lb} / \mathrm{hr} \text {. } \\
\text { A call took place with Ramsay and he requested a couple of } \\
\text { changes to the data presentation. } \\
\text { - remove negative removal values } \\
\text { - change the } x \text {-axis to } \mathrm{lb} / \text { Macf from } \mathrm{lb} / \mathrm{hr} \text {. }\end{array}$ \\
\hline
\end{tabular}


Table 1. September 1997 Dry Sorbent Injection (DSI) Operating Summary (cont.)

\begin{tabular}{|c|c|c|}
\hline Date & Test Description & Operation Summary \\
\hline $\begin{array}{l}\text { Thur. } \\
\text { Sept. 18, } 97\end{array}$ & $\begin{array}{l}\text { DSI-6, Carbon } \\
\text { Injection }(10,200 \\
\mathrm{scfm}, 275^{\circ} \mathrm{F}, 4.6 \\
\mathrm{lb} / \mathrm{hr}) \mathrm{ESP} \mathrm{A}, \mathrm{B} \\
(5)\end{array}$ & $\begin{array}{l}\text { Carbon continued through the night }(4.69-4.14 \mathrm{lb} / \mathrm{hr}) \text {. A Method } \\
101 \mathrm{~A} \text { was started at } 08: 14 \text { and } 09: 28 \text { at the ESP inlet/outlet. } \\
\text { Mercury analysis was returned from Radian, and the new values } \\
\text { were put into the summary plot and tables. }\end{array}$ \\
\hline $\begin{array}{l}\text { Fri. } \\
\text { Sept. 19, } 97\end{array}$ & $\begin{array}{l}\text { DSI-6, Carbon } \\
\text { Injection }(10,200 \\
\text { scfm, 2755, } 4.6 \\
\mathrm{lb} / \mathrm{hr}) \text { ESP A,B } \\
\text { (5) }\end{array}$ & $\begin{array}{l}\text { Carbon was allowed to continue through the night at } 5.6-4.6 \\
\mathrm{lb} / \mathrm{hr} \text {. The feeder has been increasing in its drift and consistent } \\
\text { feed rate. Sometimes large set points have to be used to get the } \\
\text { proper rate, then has to be returned to the lower set point. } \\
\text { Method 101A was started at } 08: 05 \text { and } 09: 16 \text {. Carbon was turned } \\
\text { off at 10:25, then the ESP was slow to recover to baseline values. } \\
\text { At 12:30 the facility purge began, and was shut down at 14:00. } \\
\text { Inventory was taken of the laboratory glassware and sampling } \\
\text { glassware. }\end{array}$ \\
\hline $\begin{array}{l}\text { Mon. } \\
\text { Sept. 22, } 97\end{array}$ & $\begin{array}{l}\text { DSI-6, Carbon } \\
\text { Injection }(10,200 \\
\text { scfm, } 275^{\circ} \mathrm{F}, 4.6 \\
\mathrm{lb} / \mathrm{hr}) \mathrm{ESP} \mathrm{A}, \mathrm{B} \\
\text { (5) }\end{array}$ & $\begin{array}{l}\text { I\&C was in at } 04: 00 \text { to calibrate } C E M s, P-5 A \text {, and opacity } \\
\text { monitor, no major problems found. The facility was allowed to } \\
\text { recover to baseline readings. It took most the day for the loading } \\
\text { to return, but the ESP voltage was still high. It was noticed that } \\
\text { the hot deck temperatures were lower, about } 10^{\circ} \mathrm{F} \text { lower. This } \\
\text { could have been to the cooler ambient temperatures then } \\
\text { previously seen. Mercury removal data was reduced and } \\
\text { evaluated, along with point investigation. Summaries were } \\
\text { updated and reviewed. Night instructions were left to start } \\
\text { carbon injection at } 4.6 \mathrm{lb} / \mathrm{hr} \text { is the ESP voltage returned back to } 46 \\
\text { V or to start at } 05: 00 \text {, which ever came first. }\end{array}$ \\
\hline $\begin{array}{l}\text { Tue. } \\
\text { Sept. 23, } 97\end{array}$ & $\begin{array}{l}\text { DSI-7, Carbon } \\
\text { Injection }(10,200 \\
\text { scfm, 275F, } 1.8 \\
\mathrm{lb} / \mathrm{hr}) \text { ESP A,B } \\
\text { (5) }\end{array}$ & $\begin{array}{l}\text { Carbon injection began at } 02: 15 \text { at a rate of } 4.6 \mathrm{lb} / \mathrm{hr} \text { when the ESP } \\
\text { voltage dropped to } 46 \mathrm{~V} \text {. Method } 101 \mathrm{~A} \# 1 \text { started at } 08: 05 \text { and \#2 } \\
\text { at } 09: 25 \text {. Contractors meeting was held at } 14: 00 \text {, and discussed } \\
\text { weeks plan and future testing. At 16:00 the carbon injection rate } \\
\text { was switched to } 1.8 \mathrm{lb} / \mathrm{hr} \text { for the rest of the weeks testing. }\end{array}$ \\
\hline $\begin{array}{l}\text { Wed. } \\
\text { Sept. 24, } 97\end{array}$ & $\begin{array}{l}\text { DSI-7, Carbon } \\
\text { Injection }(10,200 \\
\text { scfm, 275'F, } 1.8 \\
\mathrm{lb} / \mathrm{hr}) \text { ESP A,B } \\
(5)\end{array}$ & $\begin{array}{l}\text { Carbon injection ran through the night at } 1.8 \mathrm{lb} / \mathrm{hr} \text {. Method 101A } \\
\text { sampling started at 08:05 (\#1) and 09:25 (\#2). Carbon injection } \\
\text { continued through the day at } 1.8 \mathrm{lb} / \mathrm{hr} \text {. }\end{array}$ \\
\hline $\begin{array}{l}\text { Thur. } \\
\text { Sept. 25, } 97\end{array}$ & $\begin{array}{l}\text { DSI-7, Carbon } \\
\text { Injection }(10,200 \\
\text { scfm, 275'F, } 1.8 \\
\mathrm{lb} / \mathrm{hr}) \text { ESP A,B } \\
(5)\end{array}$ & $\begin{array}{l}\text { Carbon injection ran through the night at } 1.8 \mathrm{lb} / \mathrm{hr} \text {, with no } \\
\text { problems occurring. Sampling began at } 08: 10 \text { with Method } 101 \mathrm{~A} \\
\# 1 \text { and run } \# 2 \text { started at 09:25. At 09:30 the facility safety } \\
\text { meeting was held, covering sling and crane safety. Researched } \\
\text { other dry sorbent information. Summaries were updated and } \\
\text { reviewed, and started preparing Steering Committee slides. } \\
\text { After review of } \mathrm{SO}_{2} \text { EPA emissions data another leak in the } \\
\text { facility inlet was found. }\end{array}$ \\
\hline $\begin{array}{l}\text { Fri. } \\
\text { Sept. 26, } 97\end{array}$ & $\begin{array}{l}\text { DSI-7, Carbon } \\
\text { Injection }(10,200 \\
\text { scfm, 275'F, } 1.8 \\
\mathrm{lb} / \mathrm{hr}) \text { ESP A,B } \\
\text { (5) }\end{array}$ & $\begin{array}{l}\text { Carbon continued at } 1.8 \mathrm{lb} / \mathrm{hr} \text { through the night. Sampling was } \\
\text { conducted at the ESP inlet and outlet at } 08: 10 \text { and } 09: 25 \text {. Carbon } \\
\text { injection was turned off at 10:25. At 11:00 the ESP was switched } \\
\text { from "A\&B" field to "C" field. Facility purge was started at } \\
\text { 13:00 and shut down at 14:50. }\end{array}$ \\
\hline
\end{tabular}


Table 1. September 1997 Dry Sorbent Injection (DSI) Operating Summary (cont.)

\begin{tabular}{|c|c|c|}
\hline Date & Test Description & Operation Summary \\
\hline $\begin{array}{l}\text { Mon. } \\
\text { Sept. 29, } 97\end{array}$ & $\begin{array}{l}\text { DSI-8, Carbon } \\
\text { Injection }(10,200 \\
\mathrm{scfm}, 300^{\circ} \mathrm{F}, 4.6 \\
\mathrm{lb} / \mathrm{hr}) \text { ESP A (10) }\end{array}$ & $\begin{array}{l}\text { Facility warm was started at } 23: 35 \text {, and " } \mathrm{A} \text { " field was energized } \\
\text { at } 03: 30 \text { at } 10 \mathrm{mV} \text {. I\&C was in at } 4: 00 \text { to calibrate CEMs, P-5A, } \\
\text { and opacity monitor, no major problems found. The SDA heater is } \\
\text { going to be used once carbon injection started to maintain } \\
\text { temperature tighter at } 300^{\circ} \mathrm{F} \text {. The facility was allowed to } \\
\text { recover to baseline ESP settings and loading. This weeks data is } \\
\text { rerunning previous points that resulted in a lot of scatter in the } \\
\text { result plot of mercury removal. Contractor meeting held at 13:00 } \\
\text { to discuss options for further testing, weeks testing, and other on } \\
\text { going projects. Began to prepare summaries for monthly progress } \\
\text { reports to the steering committee. }\end{array}$ \\
\hline $\begin{array}{l}\text { Tue. } \\
\text { Sept. 30, } 97\end{array}$ & $\begin{array}{l}\text { DSI-8, Carbon } \\
\text { Injection }(10,200 \\
\text { scfm, } 300^{\circ} \mathrm{F}, 4.6 \\
\mathrm{lb} / \mathrm{hr}) \text { ESP A (10) }\end{array}$ & $\begin{array}{l}\text { Data summaries were updated and reviewed. Continued work on } \\
\text { monthly progress report. At 10:00 Method } 5 \text { was conducted on the } \\
\text { ESP outlet. The mass loading result (P-022) was } 0.206 \mathrm{lb} / \mathrm{MMBtu} \text {. }\end{array}$ \\
\hline
\end{tabular}

\section{Summary of Results}

The Dry Sorbent Injection (DSI) testing this month investigated the effects of activated carbon injection (Norit FGD carbon) upstream of an ESP to determine total mercury removal efficiencies and performance effects with regard to particulate removal efficiency. Recall that FGD carbon is a lignite-based carbon material and is primarily sold as a sorbent for removal of heavy metals species in incinerator flue gas streams. The average grind size for this dry carbon powder is approximately $95 \%$ minus 325 mesh screen $(45 \mu \mathrm{m})$. The mean particle size for this FGD carbon material has been previously analyzed and reported to be approximately $15 \mu \mathrm{m}$.

To simulate full-scale operating conditions for this test block, an appropriate inlet ESP gas flow, temperature, and outlet opacity range was selected and maintained to:

- provide a representative gas / carbon residence time through the ESP;

- prevent the formation of acid gas condensation in the ESP; and,

- simulate current/future outlet opacity performance limits.

The operating conditions required to meet these objectives were specified in the August test matrix and included an inlet ESP gas flow of $10,200 \mathrm{scfm}$ at $275^{\circ} \mathrm{F}$ with an ESP outlet particulate emission limit (pre-carbon injection) of $0.1-0.2 \mathrm{lb} / \mathrm{MBtu}$. These test conditions were continuously monitored through the ECTC DRG flow venturi and the outlet opacity and P-5A particulate monitors, and were regularly checked through EPA Method 2 (velocity traverse) and EPA Method 5 (outlet opacity) measurements. This gas flow was selected to maintain a representative gas flow residence time of 2-3 seconds through the first ESP field (" $\mathrm{A}$ " field), and a carbon residence time of 5 seconds from the point of injection to the exit of the first ESP field. The data used to determine the appropriate residence times for full-scale simulation testing are shown below in Table 2 . 


\begin{tabular}{|c|c|c|c|c|c|c|c|}
\hline $\begin{array}{c}\text { ESP INLET GAS FLOW } \\
(\mathrm{scfm})\end{array}$ & $\begin{array}{l}\text { TEMP. } \\
(\operatorname{deg} F) \\
\end{array}$ & $\begin{array}{l}\text { PRESSURE } \\
\text { (in. w.c.) }\end{array}$ & $\begin{array}{c}\text { ESP INLET GAS FLOW } \\
(\text { acfm })\end{array}$ & \begin{tabular}{|c|} 
INLET DUCT VEL \\
$(\mathrm{ft} / \mathrm{min})$
\end{tabular} & $\begin{array}{l}\text { ESP VEL } \\
(\mathrm{ft} / \mathrm{min}) \\
\end{array}$ & $\begin{array}{l}\text { ESP GAS RESIDENCE TIME } \\
(\mathrm{sec})\end{array}$ & $\begin{array}{c}\text { GAS RESIDENCE TIME/ FIELD } \\
(\mathrm{sec})\end{array}$ \\
\hline 4000 & 220 & -10 & 5281 & 1682 & 88 & 47 & 9 \\
\hline 4000 & 250 & -10 & 5514 & 1756 & 92 & 45 & 9 \\
\hline 10200 & 220 & -20 & 13815 & 4400 & 230 & 18 & 4 \\
\hline 10200 & 250 & -20 & 14425 & 4594 & 240 & 17 & 3 \\
\hline 10200 & 300 & -20 & 15441 & 4917 & 257 & 16 & 3 \\
\hline 8000 & 275 & -10 & 11417 & 3636 & 190 & 22 & 4 \\
\hline 8000 & 300 & -10 & 11805 & 3760 & 197 & 21 & 4 \\
\hline 8000 & 320 & -10 & 12116 & 3859 & 202 & 21 & 4 \\
\hline 6000 & 300 & -20 & 9083 & 2893 & 151 & 27 & 5 \\
\hline 11000 & 300 & -20 & 16652 & 5303 & 278 & 15 & 3 \\
\hline
\end{tabular}

Table 2. ESP Gas Flow Residence Time

Flue gas sampling during this testing was conducted at the ESP inlet and outlet locations using EPA Method 101A for total vapor-phase mercury measurement in the ECTC flue gas stream. During this test period, all flue gas sampling was conducted at vapor-phase mercury levels as received from the NYSEG Kintigh Station flue gas (i.e., the flue gas was not spiked/doped with any additional mercury species - elemental or ionic). During this period, measurements of the vapor-phase concentrations for total mercury at the ESP inlet (without carbon injection) indicated baseline $\mathrm{Hg}$ levels of $2-6 \mu \mathrm{g} / \mathrm{Nm}^{3}$. With this data, the various representative carbon injection rates for the test matrix were calculated as shown in Table 3.

\begin{tabular}{|c|c|c|}
\hline Carbon Injection Rate (lb/Macf) & Carbon : Mercury Ratio (lb/lb) & Carbon Injection Rate (lb/hr) \\
\hline \hline 2 & $15,000: 1$ & 1.8 \\
\hline 5 & $24,000: 1$ & 4.6 \\
\hline 10 & $55,000: 1$ & 9.2 \\
\hline
\end{tabular}

Table 3. Calculated carbon injection rates 


\section{Mercury Removal}

As testing continued this month, the data from the gas sampling periods and the lab analysis was collected and analyzed to plot the mercury removals associated with the various carbon injection rates. This data is presented below in Figure 2 for $275^{\circ} \mathrm{F}$ testing.

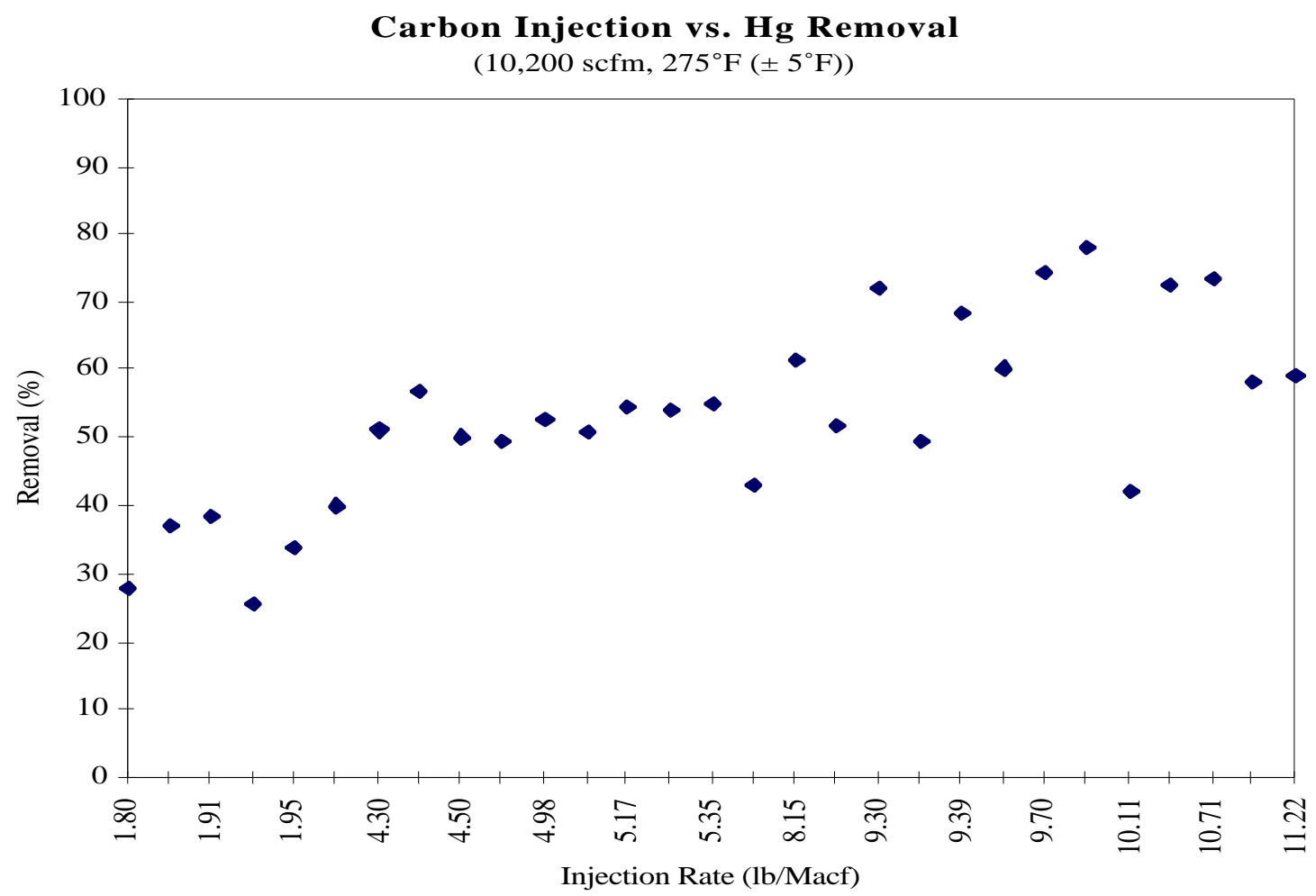

Figure 2. Total Mercury Removal vs. Carbon Injection.

As the carbon injection rates were increased in the test matrix, higher removals for total vapor-phase mercury were obtained. From a review of the data plot and the raw data, an average removal efficiency was determined for each carbon injection rate. These efficiencies are shown in Table 4 below.

\begin{tabular}{|c|c|}
\hline Carbon Injection Rate (lb/Macf) & Average Mercury Removal Efficiency (\%) \\
\hline \hline 2 & 34 \\
\hline 5 & 52 \\
\hline 10 & 63 \\
\hline
\end{tabular}

Table 4. Carbon Injection Rate vs. Average Mercury Removal

At the $5 \mathrm{lb} /$ Macf carbon injection range, an appreciable increase in total vapor-phase mercury removal was measured across the ESP, and the average removal efficiency was calculated at $52 \%$. 
When the carbon injection rate was doubled to $10 \mathrm{lb} /$ Macf during this test period, the corresponding increase in total vapor-phase mercury removal efficiency was only about $10 \%$ (measured at $63 \%$ mercury removal). This was the highest carbon injection rate investigated in this test matrix. Also, in reviewing the data and plots, it appears that the mercury removal efficiency of the ESP begins to plateau at the $10 \mathrm{lb} /$ Macf carbon injection rate. However, this cannot be confirmed until additional testing at higher injection rates is completed.

\section{ESP Performance}

During the testing of activated carbon injection for total vapor-phase mercury removal this month, the effects of carbon injection on ESP performance were also measured. This effort was conducted during the baseline operating conditions during the period $(10,200 \mathrm{scfm}$ inlet ESP gas flow and an inlet ESP gas temperature of $275^{\circ} \mathrm{F}$ ). To study ESP performance, the ESP outlet opacity was continuously monitored (with and without carbon injection) through the use of several methods:

- Environmental Systems Corp. (ESC) P-5A mass concentration particulate monitor;

- regular EPA Method 5 gas samples, and;

- continuous \% opacity readings.

Daily voltage/current (V/I) readings were also taken across each transformer rectifier (TR) set energized in the ESP, and weekly air load readings taken before each weekly start-up of the ESP. This data, when considered with the measurements taken on the flyash collected from the ESP ash hoppers (ash loss-onignition (LOI) content and $\mathrm{pH}$ ), allowed the impact of sorbent (carbon) injection to be characterized with respect to ESP performance.

The test data collected this month for ESP performance showed some increases in the secondary voltages across the energized ESP fields during the higher injection rates of carbon injection this period (resulting in improved ESP efficiency/decreased opacity). However, the data collected from this period is scattered and requires additional review.

\section{Future Testing}

Testing in October will continue with the Dry Sorbent Injection (DSI) investigation across the ECTC ESP. Based on the current test matrix, the October testing will investigate the effects of mercury removal and ESP performance at the carbon injection rates of $0,2,5$, and $10 \mathrm{lb} /$ Macf at a controlled inlet ESP gas temperature of $300^{\circ} \mathrm{F} \pm 5^{\circ} \mathrm{F}$. This test period will be used to repeat an earlier series of $300^{\circ} \mathrm{F}$ tests from the matrix (now at a more constant inlet ESP temperature). 
APPENDIX A

TEST SCHEDULE(S) 


\begin{tabular}{|c|c|c|c|c|c|c|c|c|c|c|c|c|c|}
\hline & \multicolumn{13}{|c|}{1996} \\
\hline & JAN & FEB & MAR & APR & MAY & JUN & JUL & AUG & SEP & OCT & NOV & & \\
\hline $\begin{array}{l}\text { 4.0 MW Pilot } \\
\text { FGD Unit }\end{array}$ & \multicolumn{2}{|c|}{$\begin{array}{l}\text { EPRI Wet FGD } \\
\text { Toxics Testing }\end{array}$} & $\begin{array}{l}\text { DOE// } \\
\text { Mercu } \\
\text { Contro }\end{array}$ & $\begin{array}{l}\text { DA Pha } \\
\text { and HA } \\
\text { with We }\end{array}$ & & \multicolumn{2}{|c|}{$\begin{array}{l}\text { EPRI Wet FGD } \\
\text { Toxics Testing }\end{array}$} & \begin{tabular}{|l} 
Thin \\
Tes \\
Rot \\
Tec
\end{tabular} & & $\begin{array}{l}\text { EPRI Toxics } \\
\text { Removal } \\
\text { Testing }\end{array}$ & \multicolumn{2}{|c|}{$\begin{array}{l}\text { EPRI } \\
\text { SOx/NOx } \\
\text { Process } \\
\text { Testing } \\
\end{array}$} & \begin{tabular}{|l} 
ECTC \\
Fall \\
Outage
\end{tabular} \\
\hline $\begin{array}{l}0.4 \text { MW Mini- } \\
\text { Pilot FGD Unit }\end{array}$ & \multicolumn{2}{|c|}{ UNIT DOWN } & \multicolumn{11}{|c|}{ DOE/PRDA Phase I - Multiple Pollutant Removal Using the Condensing Heat Exchanger (CHX) } \\
\hline
\end{tabular}

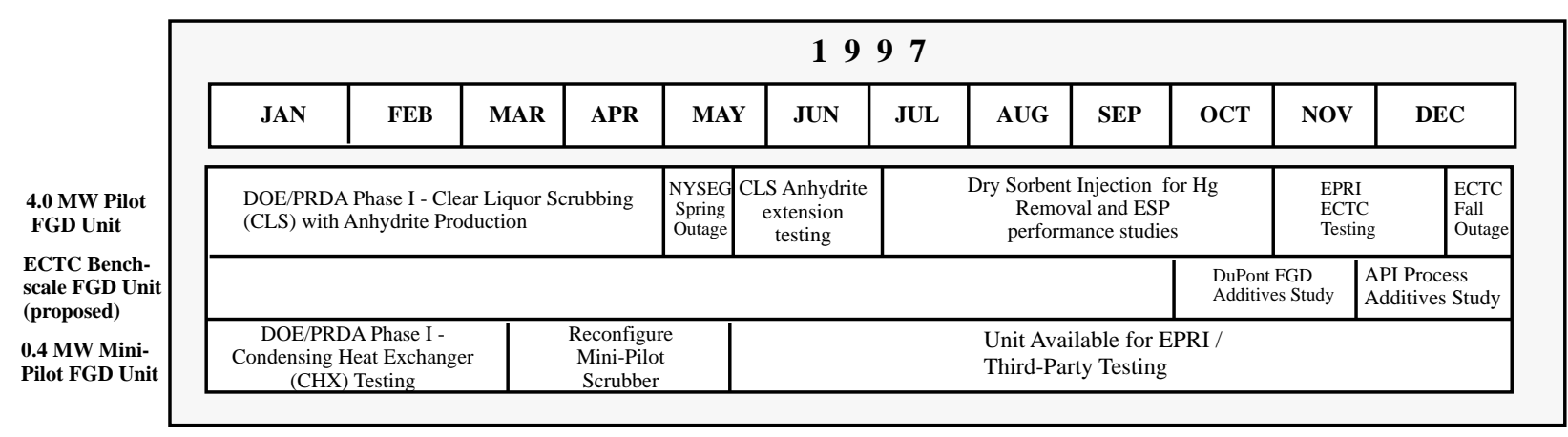

\begin{tabular}{|c|c|c|c|c|c|c|c|c|c|c|c|c|}
\hline & \multicolumn{12}{|c|}{1998 (proposed) } \\
\hline & JAN & FEB & MAR & APR & MAY & JUN & JUL & AUG & SEP & OCT & NOV & DEC \\
\hline $\begin{array}{l}\text { 4.0 MW Pilot } \\
\text { Wet FGD Unit }\end{array}$ & \multicolumn{6}{|c|}{$\begin{array}{c}\text { DOE/PRDA Phase II } \\
\text { Clear Liquor Scrubbing with Anhydrite }\end{array}$} & \multicolumn{3}{|c|}{$\begin{array}{l}\text { DOE/PRDA Phase II } \\
\text { Condensing Heat Exchanger } \\
\text { (CHX) Testing }\end{array}$} & \multicolumn{3}{|c|}{ EPRI / Third-Party Testing } \\
\hline $\begin{array}{l}\text { 0.4 MW Mini- } \\
\text { Pilot FGD Unit }\end{array}$ & \multicolumn{12}{|c|}{ EPRI / Third-Party Testing } \\
\hline
\end{tabular}

ECTC Test Schedule ('96 - '98) 
APPENDIX B

PROCESS/ANALYTICAL DATA SUMMARY 


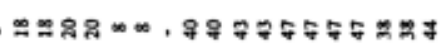

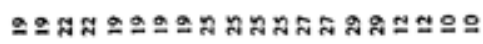

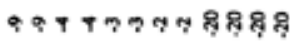

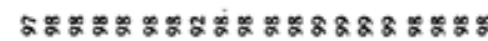

중 :

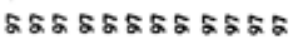

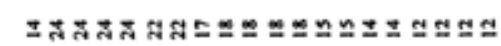

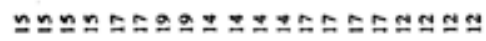

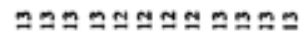

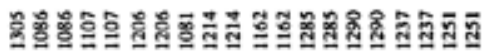

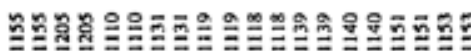

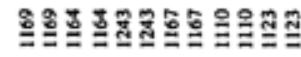

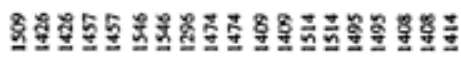

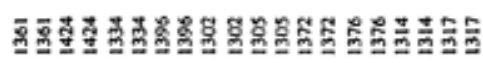

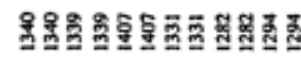

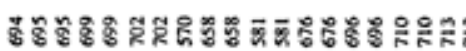

정형ำำ

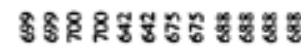

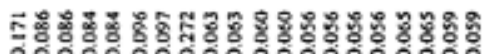

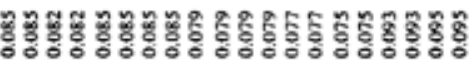

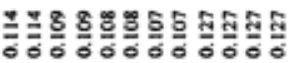

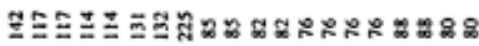

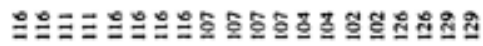

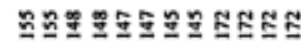

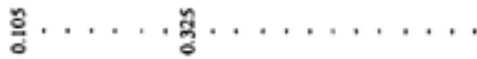

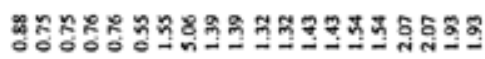

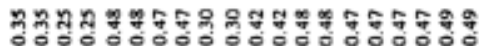

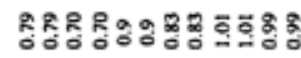

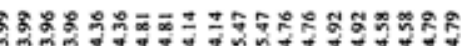

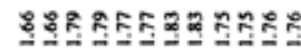

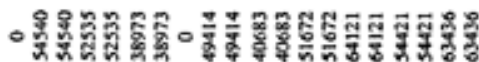

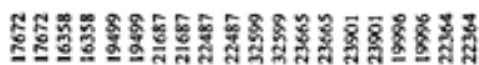

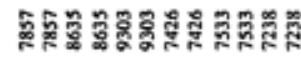
$\ldots \ldots \ldots \ldots \ldots$

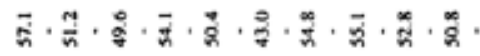

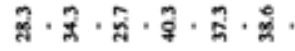

줄

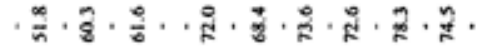

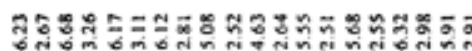
(ํ)

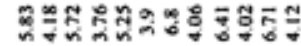

赵

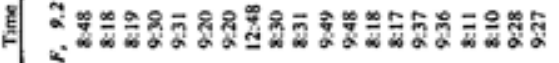

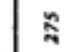

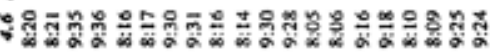

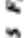

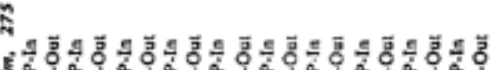

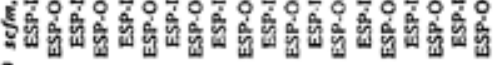

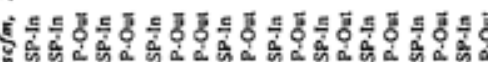

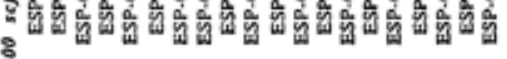

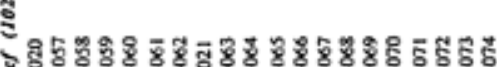
ร

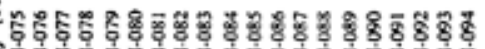

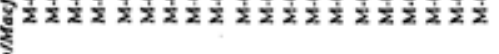

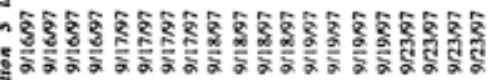
ษ

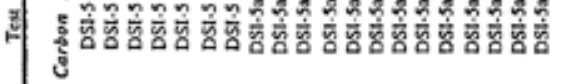
₹ํํㅇํㅇํ

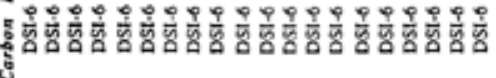

ङ

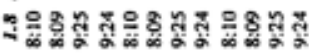
4

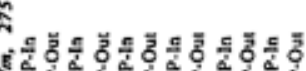

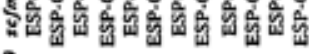
ํํำ

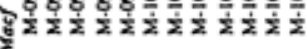
4.

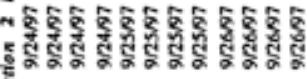
ร

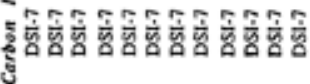




\section{ECTC COSPONSORS DISTRIBUTION}

Mr. John E. Smigelski

New York State Electric \& Gas

Corporate Drive, Kirkwood Ind. Park

P. O. Box 5224

Binghamton, NY 13902-5224

Ph: (607) 762-8688

Fax: (607) 762-8457

Dr. Gerald Janik

New York State Electric \& Gas

Corporate Drive, Kirkwood Ind. Park

P. O. Box 5224

Binghamton, NY 13902-5224

Ph: (607) 762-4318

Fax: (607) 762-8457
Ms. JoAnn C. Zysk

U.S. Department of Energy

Federal Energy Technology Center

P. O. Box 10940, MS 900-33

Pittsburgh, PA 15236

Ph: (412) 892-6200

Fax: (412) 892-6216

Mr. Michio Kurihara

Electric Power Development Co., Ltd.

15-1, Ginza 6-Chome, Chuo-ku

Tokyo, 104 JAPAN

Ph: (81) 3-3546-9404

Fax: (81) 3-3546-9482

Ms. Debra DiMeo

Empire State Electric Energy Res. Corp.

1515 Broadway

New York, NY 10036

Ph. (212) 302-1212

Fax: (212) 302-1377

\section{EPRI DISTRIBUTION}
G. Andes
T. Armor
M. Miller
G. Offen
R. Rhudy W. Chow
R. Glover 